\section{Hydroponic Production of Purslane as a Sodium-removing Vegetable in NaCl-rich Nutrient Solution}

\author{
Yun Kong and Youbin Zheng ${ }^{1}$ \\ School of Environmental Sciences, University of Guelph, Guelph, Ontario \\ N1G2W1, Canada; and Vineland Research and Innovation Centre, Vineland, \\ Ontario, Canada
}

Additional index words. biomass accumulation, cultivar difference, growth stage, $\mathrm{NaCl}$ concentration, plant growth, Portulaca oleracea, sodium removal

\begin{abstract}
To evaluate the potential of producing purslane (Portulaca oleracea L.) as a sodium ( $\mathrm{Na}$ )-removing vegetable hydroponically at moderate $\mathrm{NaCl}$ salinity, two cultivars (Green and Golden) were grown in solutions with added $0,6,8$, and $10 \mathrm{~mm} \mathrm{NaCl}$ (the actual $\mathrm{Na}^{+}$concentrations $\approx 2,8,10$, and $12 \mathrm{~mm}$, respectively). At harvest, 26 days after transplanting, apparent growth and biomass accumulation were not negatively affected by 6 to $10 \mathrm{~mm}$ added $\mathrm{NaCl}$ compared with $\mathrm{O}$ mu added $\mathrm{NaCl}$. However, with the increase of added $\mathrm{NaCl}$ concentration from 0 to 6 to $10 \mathrm{~mm}$, the sodium removal showed a 1- to 3-fold increase up to 0.26 to $0.41 \mathrm{mmol} / \mathrm{plant}$, and 225.7 to $300.2 \mathrm{mmol} \cdot \mathrm{kg}^{-1} \mathrm{dry}$ weight (DW) or 0.90 to $1.32 \mathrm{mmol} \cdot \mathrm{L}^{-1} \mathrm{H}_{2} \mathrm{O}$, respectively. 'Green' produced greater biomass and removed more sodium per plant than 'Golden'. 'Golden' had more of a dwarfed and compact canopy than 'Green'. Sodium removal rate (mmol/plant/day) was the highest during the first 7 days after transplanting, but the fresh weight increase rate (g/plant/day) increased gradually as growth progressed. Results suggest that it is possible to hydroponically produce purslane in nutrient solutions with 8 to $12 \mathrm{~mm} \mathrm{Na}^{+}$. Despite the high sodium-removal capability, purslane cannot be used to reduce $\mathrm{Na}^{+}$concentrations in NaCl-rich hydroponic solutions. The biomass yield and the sodium removal of individual plants were affected by different cultivars and time after transplanting.
\end{abstract}

One of the major problems in closed hydroponic systems is the accumulation of salt ions, especially $\mathrm{Na}^{+}$and $\mathrm{Cl}^{-}$, in reused solutions (Savvas et al., 2005). For most plant species, $\mathrm{Na}^{+}$appears to reach a toxic concentration before $\mathrm{Cl}^{-}$(Munns and Tester, 2008), resulting in $\mathrm{Na}^{+}$toxicity from a combination of osmotic and ionic stresses (Kronzucker and Britto, 2011). To prevent high $\mathrm{Na}^{+}$levels in the rhizosphere, growers may periodically permit salt leaching (Varlagas et al., 2010). For example, in The Netherlands, discharge from closed hydroponic systems is allowed if $\mathrm{Na}^{+}$concentration reaches $6 \mathrm{~mm}$ for cucumber or $8 \mathrm{~mm}$ for tomato during production (Van Os, 1998). Discharging used nutrient solution can pollute the environment and sometimes even results in soil salinization (Varlagas et al., 2010). One way to address this problem is to use these solutions for the cultivation of another economically valuable crop, which has a high salt tolerance and the ability to accumulate sodium (Grieve and Suarez, 1997).

Received for publication 30 July 2013. Accepted for publication 25 Nov. 2013

We thank Mary Jane Clark, Eric Rozema, Katherine Vinson, and Xiulin Tian for their technical support and informative discussions during the experiment. Thanks also to the anonymous reviewers for their very useful suggestions on the revision of this manuscript.

${ }^{1}$ To whom reprint requests should be addressed; e-mail yzheng@uoguelph.ca.
Purslane (Portulaca oleracea L.) is not only a salt-tolerant plant (Kilic et al., 2008; Shannon and Grieve, 1999), but also a good salt-removing crop (Aksoy et al., 2003; Grieve and Suarez, 1997), capable of removing up to $65 \mathrm{~kg} \cdot \mathrm{ha}^{-1}$ of $\mathrm{Na}^{+}$in one growing season (Kilic et al., 2008). It has been recommended as a potential intercrop to remove salt in orchards (Kilic et al., 2008, 2010) and an excellent candidate for inclusion in saline drainage water reuse systems (Grieve and Suarez, 1997). However, these studies have been carried out under soil or sand culture conditions (Grieve and Suarez, 1997; Kilic et al., 2008,2010 ), and the related information is not available under hydroponic conditions, because $\mathrm{Na}^{+}$uptake in plants can be affected by culture medium (Liu, 2002).

In addition, purslane is a traditional food crop in some Mediterranean, Central American, and Asian countries (Cros et al., 2007; Grieve and Suarez, 1997) and has now become a potential key vegetable crop worldwide because of its high nutritive and antioxidant properties (Uddin et al., 2012b; Wenzel et al., 1990). Recently, hydroponic production of purslane, as the easiest and cheapest growing method, has been gaining more and more attention as a result of the shorter cultivation cycles, higher planting densities, and clean and easily packed products compared with soil-based culture (Cros et al., 2007; Kaşkar et al., 2008). Furthermore, previous studies indicated that shoots had considerably higher $\mathrm{Na}^{+}$content than roots (Aksoy et al., 2003;
Tester and Davenport, 2007) and, also, a tight coupling has been observed between plant growth (especially shoot growth) and $\mathrm{Na}^{+}$ uptake (Lv et al., 2012). So it may be possible to accumulate $\mathrm{Na}^{+}$in purslane shoots at reasonably high levels without adversely affecting biomass productivity or, in other words, to hydroponically produce purslane as a sodium-removing vegetable.

Previous related studies in purslane were carried out separately on salt removal (Grieve and Suarez, 1997; Kilic et al., 2008) and vegetable production (Cros et al., 2007; Lara et al., 2011), and the $\mathrm{NaCl}$ concentrations in the solution used for growing purslane were totally different in these two categories of studies. In the salt removal studies (Grieve and Suarez, 1997; Kilic et al., 2008), the concentrations of $\mathrm{NaCl}$ treatment were usually higher up to more than $50 \mathrm{~mm}$, but in the vegetable production studies (Cros et al., 2007; Lara et al., 2011), $\mathrm{NaCl}$ was not added to solutions and its concentrations were not known (should be very low). Currently, there is a lack of information regarding the effects of moderate $\mathrm{NaCl}$ concentrations $(\approx 6$ to $10 \mathrm{~mm}$ ) on biomass production and sodium removal in purslane.

An appropriate selection of cultivars is vital to evaluate the potential of hydroponic production of purslane as a sodium-removing vegetable. Commercially available purslane cultivars are either green- or golden-leafed genotypes (Seedaholic, 2013). In studies aimed at evaluating growth and yield responses of purslane, significant differences were observed in plant growth between green- and golden-leafed genotypes in hydroponic solutions without added $\mathrm{NaCl}$ (Lara et al., 2011; Palaniswamy et al., 2000). However, in salt removal studies on purslane, only one genotype was used to evaluate $\mathrm{Na}^{+}$removal capacity under high $\mathrm{NaCl}$ concentrations (Grieve and Suarez, 1997; Kilic et al., 2008). Consequently, comparisons of sodium removal and biomass accumulation between green- and golden-leafed purslane genotypes are needed under moderate $\mathrm{NaCl}$ concentrations $(\approx 6$ to $10 \mathrm{~mm})$.

Determining how growth stage affects purslane biomass accumulation and sodium removal is important to predict the ideal harvest time of hydroponically produced purslane when used as a sodium-removing vegetable crop. A long production time (delaying the harvest time) would result in high biomass (i.e., increased yield); however, most crops exhibit higher $\mathrm{Na}^{+}$uptake efficiency during vegetative vs. reproductive growth (Subbarao et al., 2003). Uddin et al. (2012a) found that $\mathrm{Na}^{+}$concentration in dried purslane leaves decreased with plant maturity when evaluated over $60 \mathrm{~d}$ after transplanting young plants from the field into potted soil. In contrast, Kilic et al. (2008) reported that percent $\mathrm{Na}^{+}$in dry purslane shoots was highest at the last harvest, but it was evaluated only 12 to $38 \mathrm{~d}$ after germination in a sand culture system. Therefore, further clarification is needed to evaluate how growth stages affect sodium removal and biomass accumulation of 
hydroponically grown purslane during a longer growth period.

The objectives of the present study were to assess 1) the potential of producing purslane hydroponically under moderate $\mathrm{NaCl}$ concentrations ( $\approx 6$ to $12 \mathrm{~mm}) ; 2$ ) whether purslane can be used to remove sodium from hydroponic solution with moderate $\mathrm{NaCl}$ salinity; and 3) how $\mathrm{NaCl}$ concentrations, cultivar type, and growth stage affect purslane growth and sodium removal from a hydroponic system.

\section{Materials and Methods}

Plant materials and growing conditions. The research was conducted in a greenhouse in the Edmund C. Bovey building at the University of Guelph, Guelph, Ontario, Canada (lat. $43^{\circ} 33^{\prime} \mathrm{N}$, long. $80^{\circ} 15^{\prime} \mathrm{W}$ ). Seeds of two purslane cultivars (Golden and Green; William Dam Seeds Co., Dundas, Ontario, Canada) were sown in rockwool cubes (1.5inch Starter Plugs, Grodan Inc., Ontario, Canada) on 4 Jan. 2013. After germination, the seedlings were thinned to one plant per rockwool cube. Four plants (each in one rockwool cube), with two pairs of true leaves per plant, were transplanted, $26 \mathrm{~d}$ after sowing onto a Styrofoam disk floating on nutrient solution in a plastic pot (14-cm top and $12-\mathrm{cm}$ bottom diameters $\times 15 \mathrm{~cm}$ high). Each pot contained $\approx 1.5 \mathrm{~L}$ of nutrient solution with macronutrients $\left(\mathrm{mmol} \cdot \mathrm{L}^{-1}\right) 19.9$ nitrogen, 1.2 phosphorus, 10.8 potassium, 2.4 calcium, 0.1 magnesium, and 3.2 sulfur and micronutrients $\left(\mu \mathrm{mol} \cdot \mathrm{L}^{-1}\right) 8.3$ copper, 19.1 boron, 9.6 manganese, 8.2 zinc, 1.7 molybdenum, 18.8 iron, and 0.4 EDTA. $\mathrm{NaCl}$ was added to the nutrient solutions to achieve four concentration treatments: $0,6,8$, and $10 \mathrm{~mm}$ added $\mathrm{NaCl}$. The initial $\mathrm{Na}^{+}$concentration, electrical conductivity (EC), and $\mathrm{pH}$ values of the nutrient solutions are presented in Table 1. The nutrient solutions were changed every $7 \mathrm{~d}$ (except the last time, which was $5 \mathrm{~d}$ as a result of harvest) to reduce nutrient and $\mathrm{NaCl}$ concentration variability during the experiment. Nutrient solution $\mathrm{pH}$ ranged between 5.5 and 7.0 as measured at the end of each week

Table 1. Initial $\mathrm{Na}^{+}$concentrations, electrical conductivity (EC), and $\mathrm{pH}$ values of nutrient solutions used for hydroponic purslane production.

\begin{tabular}{cccc}
\hline Added $\mathrm{NaCl}$ concn $(\mathrm{mM})$ & Measured $\mathrm{Na}^{+}$concn $(\mathrm{mM})$ & $\mathrm{EC}\left(\mathrm{dS} \cdot \mathrm{m}^{-1}\right)$ & $\mathrm{pH}$ \\
\hline 0 & $1.8 \pm 0.1^{\mathrm{z}}$ & $2.95 \pm 0.10$ & $6.9 \pm 0.09$ \\
6 & $7.9 \pm 0.1$ & $3.59 \pm 0.09$ & $6.9 \pm 0.08$ \\
8 & $9.9 \pm 0.2$ & $3.84 \pm 0.09$ & $6.9 \pm 0.08$ \\
10 & $11.9 \pm 0.3$ & $4.04 \pm 0.09$ & $6.9 \pm 0.08$ \\
\hline
\end{tabular}

${ }^{\mathrm{z}}$ Data are means \pm SE $(n=4)$.
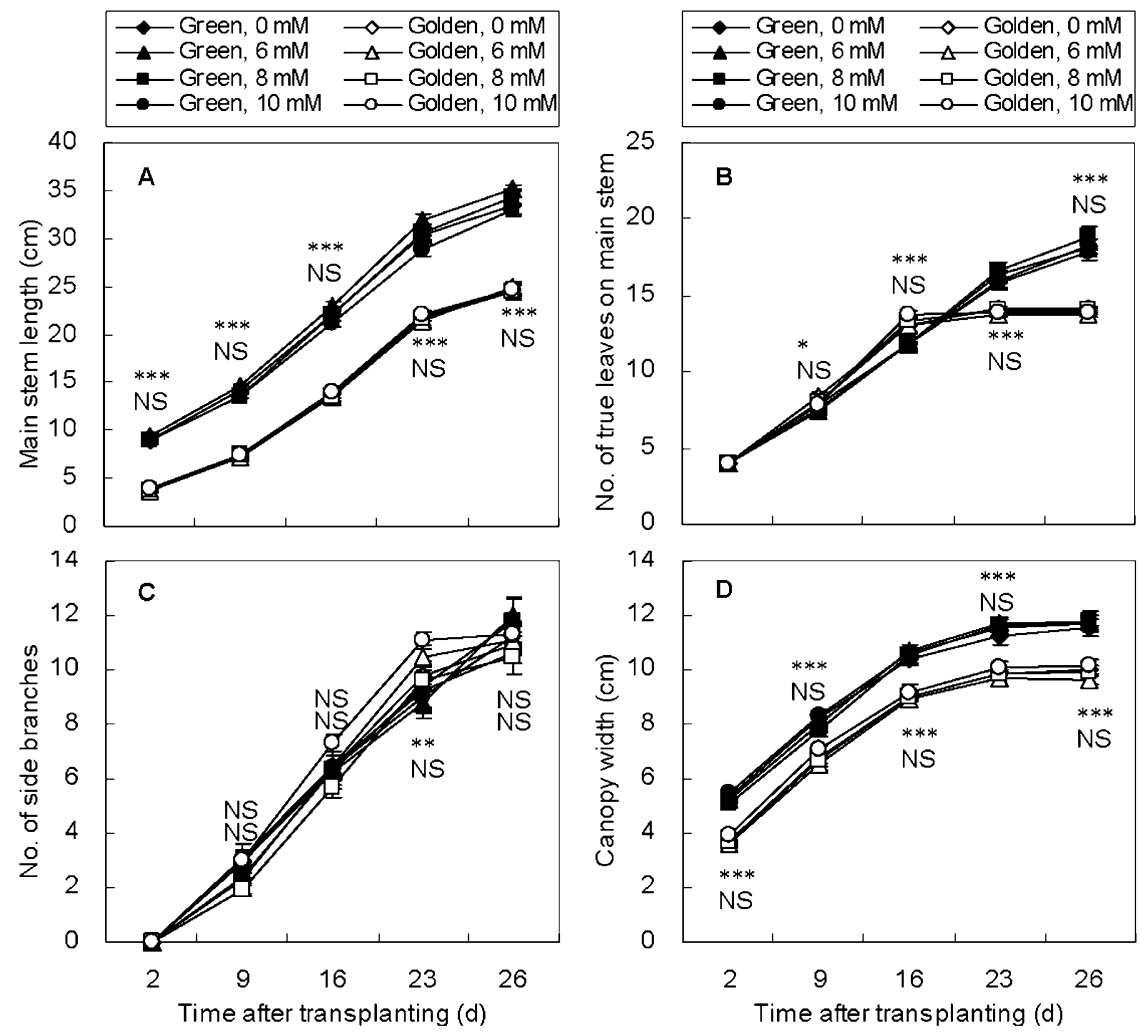

Fig. 1. Main stem length (A), number of true leaves $(\mathbf{B})$, and number of side branches $(\mathbf{C})$ on the main stem and canopy width (D) of 'Green' and 'Golden' purslane grown in hydroponic solutions with different added $\mathrm{NaCl}$ concentrations at different growth stages. Data are means $\pm \mathrm{SE}(\mathrm{n}=10)$. Where bars are not visible, SE does not exceed the size of the symbol. At each time point after transplanting, Ns, *, **, or *** next to the data indicates that the effects of different cultivars (upper symbol) or $\mathrm{NaCl}$ concentrations (lower symbol) are not significant or significant at $P \leq 0.05,0.01$, or 0.001 , respectively. before the solutions were renewed. Pots were arranged in a randomized block design with 10 blocks and eight treatments within each block (i.e., four $\mathrm{NaCl}$ concentrations for each of two purslane cultivars per block).

The greenhouse conditions were set at 18-h light/6-h dark by supplementing natural sunlight with high pressure sodium lamps to achieve a photosynthetic photon flux at canopy level averaging no less than $396.7 \pm 33.5$ $\mu \mathrm{mol} \cdot \mathrm{m}^{-2} \cdot \mathrm{s}^{-1}$, and 20 to $25^{\circ} \mathrm{C}$ light $/ 18.9^{\circ} \mathrm{C}$ dark with a relative humidity between $60 \%$ to $80 \%$.

Apparent growth measurements. One plant from each pot was randomly chosen from each block for growth measurements. Each week the following attributes were measured: main stem length, true leaf number on the main stem, side branch number on the main stem, and canopy width. Final harvest was carried out when the terminal flower bud cluster appeared on the main stem of both cultivars of purslane (26 d after transplanting).

Biomass accumulation estimation. Plant fresh weight (FW) increase during each week was determined by weighing the solutions and plants at the beginning and the end of each week, because the rockwool and Styrofoam weights were constant. Then, FW increase rate was calculated as follows:

$\mathrm{FW}$ increase rate $(\mathrm{g} / \mathrm{plant} / \mathrm{d})$

$$
=\frac{\left(\mathrm{W}_{\mathrm{ft}}-\mathrm{W}_{\mathrm{fps}}\right)-\left(\mathrm{W}_{\mathrm{it}}-\mathrm{W}_{\mathrm{ips}}\right)}{4 \times \mathrm{t}}
$$

where $\mathrm{W}_{\mathrm{ft}}$ and $\mathrm{W}_{\mathrm{it}}$ are the final and initial total weight $(\mathrm{g})$ of each pot together with solution, plants, rockwool cubes, and Styrofoam during each week, respectively. $\mathrm{W}_{\mathrm{fps}}$ and $\mathrm{W}_{\mathrm{ips}}$ are the final and initial weight $(\mathrm{g})$ of each pot and solution during each week, respectively. $t$ is the treatment time (d) of each week, and 4 is the number of seedlings in each pot.

At the time of harvest, each plant was cut at the base above the rockwool cube, and the remaining plant tissue was separated from the rockwool cube, washed with tap water, and then rinsed with deionized water. FW of plant tissue from above and within the rockwool cube were measured respectively. Plant tissue DWs were determined by drying in an oven at $65^{\circ} \mathrm{C}$ until a constant weight was achieved.

Marketable yield and water use efficiency were calculated as follows:

Marketable yield $\left(\mathrm{kg} \cdot \mathrm{m}^{-2}\right)=\frac{\mathrm{FW}_{\mathrm{s}}}{1000 \times 0.015}$

where $\mathrm{FW}_{\mathrm{s}}$ is the fresh weight $(\mathrm{g})$ of harvested plant tissue above the rockwool cube from each pot and 0.015 is the top area $\left(\mathrm{m}^{2}\right)$ of each pot.

Water use efficiency $\left(\mathrm{g} \mathrm{FW} / \mathrm{L} \mathrm{H}_{2} \mathrm{O}\right)$

$$
=\frac{\sum_{i=1}^{4} \Delta \mathrm{FW}_{\mathrm{i}}}{\sum_{\mathrm{i}=1}^{4} \Delta \mathrm{V}_{\mathrm{i}}}
$$

where $\Delta \mathrm{FW}_{\mathrm{i}}$ is the increased fresh weight $(\mathrm{g})$ of plants in each pot during the $\mathrm{i}^{\text {th }}$ week $(\mathrm{i}=1$, 

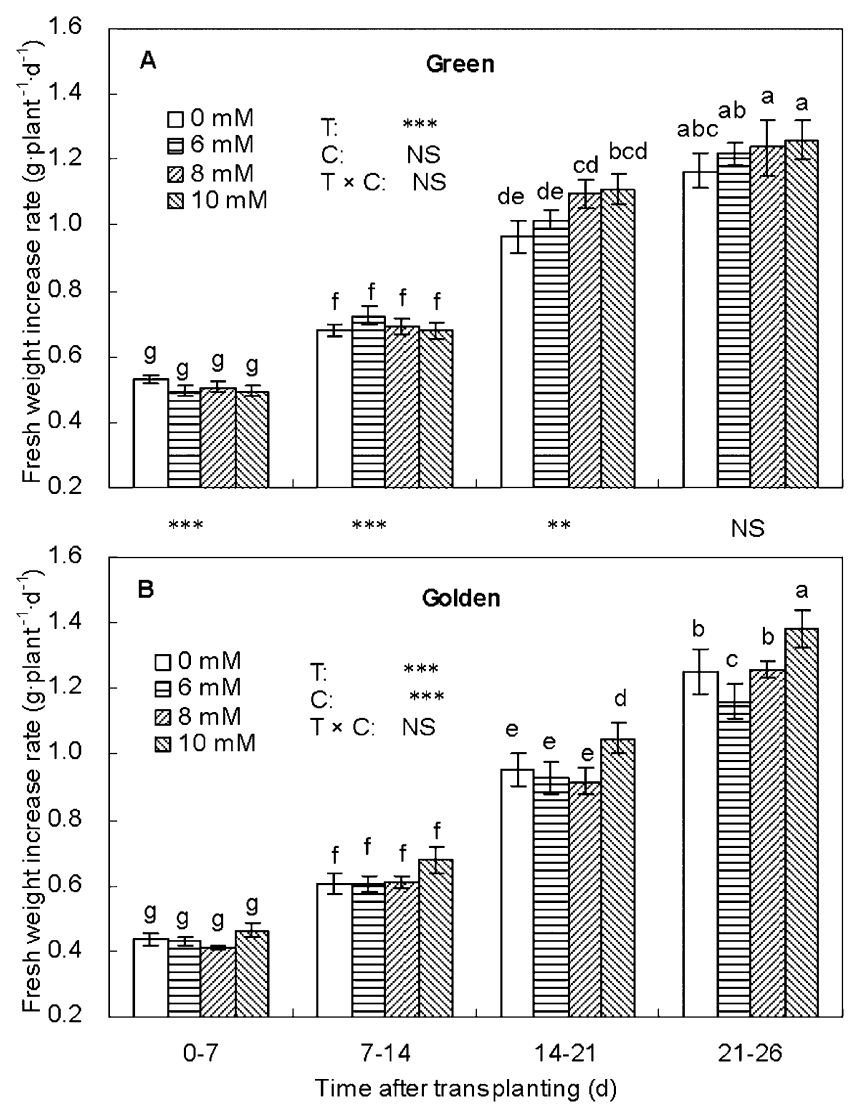

Fig. 2. Fresh weight increase rate of 'Green' (A) and 'Golden' (B) purslane grown in hydroponic solutions with different added $\mathrm{NaCl}$ concentrations at different growth stages. Data are means $\pm \mathrm{SE}(\mathrm{n}=10)$. Bars bearing the same letter are not significantly different at $P \leq 0.05$ according to Duncan's new multiple range test. At the same time points after transplanting, Ns, **, or *** between $(\mathbf{A})$ and $(\mathbf{B})$ indicates that the differences between the two cultivars are not significant or significant at $P \leq 0.01$ or 0.001 , respectively. Within the same cultivar, time after transplanting $(\mathrm{T}), \mathrm{NaCl}$ concentration $(\mathrm{C})$, or the interaction of time after transplanting and $\mathrm{NaCl}$ concentration $(\mathrm{T} \times \mathrm{C})$, followed by $\mathrm{NS}$ or *** denote treatment effects are not significant or significant at $P \leq 0.001$, respectively.

Table 2. Biomass accumulation, marketable yield, and water use efficiency in 'Green' and 'Golden' purslane grown in hydroponic solutions with different added $\mathrm{NaCl}$ concentrations.

\begin{tabular}{|c|c|c|c|c|}
\hline $\begin{array}{l}\text { Added } \mathrm{NaCl} \\
\text { concn }(\mathrm{mm})\end{array}$ & Fresh wt (g/plant) & Dry wt (g/plant) & $\begin{array}{c}\text { Marketable } \\
\text { yield }\left(\mathrm{kg} \cdot \mathrm{m}^{-2}\right)\end{array}$ & $\begin{array}{l}\text { Water use efficiency } \\
\quad\left(\mathrm{g} \mathrm{FW} / \mathrm{L} \mathrm{H}_{2} \mathrm{O}\right)\end{array}$ \\
\hline \multicolumn{5}{|l|}{ Green } \\
\hline 0 & $22.1 \pm 0.7^{\mathrm{z}} \mathrm{a}^{\mathrm{y}}$ & $1.30 \pm 0.05 \mathrm{a}$ & $5.43 \pm 0.18 \mathrm{a}$ & $80.2 \pm 1.6 b$ \\
\hline 6 & $22.8 \pm 0.6 \mathrm{a}$ & $1.33 \pm 0.03 \mathrm{a}$ & $5.58 \pm 0.14 \mathrm{a}$ & $85.6 \pm 1.4 \mathrm{a}$ \\
\hline 8 & $23.3 \pm 0.9 \mathrm{a}$ & $1.33 \pm 0.06 \mathrm{a}$ & $5.75 \pm 0.22 \mathrm{a}$ & $86.8 \pm 1.4 \mathrm{a}$ \\
\hline 10 & $23.1 \pm 0.9 \mathrm{a}$ & $1.39 \pm 0.04 \mathrm{a}$ & $5.73 \pm 0.21 \mathrm{a}$ & $84.9 \pm 1.8 \mathrm{a}$ \\
\hline \multicolumn{5}{|l|}{ Golden } \\
\hline 0 & $21.2 \pm 1.0 \mathrm{ab}$ & $1.13 \pm 0.06 \mathrm{~b}$ & $5.21 \pm 0.26 \mathrm{ab}$ & $79.6 \pm 2.1 \mathrm{~b}$ \\
\hline 6 & $20.1 \pm 1.1 \mathrm{~b}$ & $1.06 \pm 0.06 \mathrm{~b}$ & $4.90 \pm 0.26 \mathrm{~b}$ & $83.2 \pm 2.1 \mathrm{ab}$ \\
\hline 8 & $20.7 \pm 0.5 b$ & $1.12 \pm 0.03 \mathrm{~b}$ & $5.08 \pm 0.13 b$ & $83.0 \pm 1.6 \mathrm{ab}$ \\
\hline 10 & $23.1 \pm 1.1 \mathrm{a}$ & $1.32 \pm 0.07 \mathrm{a}$ & $5.71 \pm 0.27 \mathrm{a}$ & $84.1 \pm 1.7 \mathrm{a}$ \\
\hline \multicolumn{5}{|c|}{ ANOVA results } \\
\hline $\mathrm{G}^{\mathrm{x}}$ & ** & $* * *$ & ** & NS \\
\hline $\mathrm{C}^{\mathrm{x}}$ & NS & ** & NS & ** \\
\hline $\mathrm{G} \times \mathrm{C}^{\mathrm{x}}$ & NS & NS & NS & NS \\
\hline
\end{tabular}

${ }^{2}$ Data are means \pm SE $(n=10)$.

${ }^{y}$ Different letters within a column denote significant differences $(P \leq 0.05)$ according to Duncan's new multiple range test.

${ }^{\mathrm{x}} \mathrm{G}, \mathrm{C}$, and $\mathrm{G} \times \mathrm{C}$ are sources of variation, which indicate purslane cultivar, $\mathrm{NaCl}$ concentration, and interaction of purslane cultivar and $\mathrm{NaCl}$ concentration, respectively.

Ns, **, ***Nonsignificant or significant at $P \leq 0.01$ or 0.001 , respectively.

$\mathrm{FW}=$ fresh weight; ANOVA $=$ analysis of variance.

2, 3, and 4), which can be estimated from Eq. (1), and $\Delta \mathrm{V}_{\mathrm{i}}$ is the volume (L) of consumed water in each pot during the $i^{\text {th }}$ week $(i=1,2$,
3 , and 4). The initial and final volume of nutrient solution was measured weekly per pot and the difference in solution volume was assumed to be the weekly volume of water consumed by the four plants in each pot.

Sodium removal evaluation. A subsample of the fresh and week-old nutrient solution was analyzed for $\mathrm{Na}^{+}$concentration using a portable $\mathrm{pH} / \mathrm{ISE}$ meter and sodium electrode (Thermo Orion Model 290A, Waltham, MA) $\mathrm{Na}^{+}$removal rate of the plants in each pot per week was calculated as follows:

$$
\begin{aligned}
& \mathrm{Na}^{+} \text {removal rate }(\mathrm{mmol} / \text { plant } / \mathrm{d}) \\
& =\frac{\mathrm{V}_{\mathrm{i}} \times \mathrm{C}_{\mathrm{i}}-\mathrm{V}_{\mathrm{f}} \times \mathrm{C}_{\mathrm{f}}}{4 \times \mathrm{t}}
\end{aligned}
$$

where $V_{i}$ and $V_{f}$ are the initial and final volumes (L) of solution in each pot during each week, respectively; and $\mathrm{C}_{\mathrm{i}}$ and $\mathrm{C}_{\mathrm{f}}$ are the initial and final $\mathrm{Na}^{+}$concentrations (mM) in the solution in each pot during each week, respectively. $t$ is the treatment time (d) of each week, and 4 is the number of seedlings in each pot. The $\mathrm{Na}^{+}$uptake by rockwool and Styrofoam was subtracted by setting the blank controls (i.e., transplanting only rockwool and Styrofoam without plants into nutrient solution with different $\mathrm{NaCl}$ concentrations).

At harvest, total $\mathrm{Na}^{+}$removal amount of per plant was calculated as follows:

$$
\begin{aligned}
& \mathrm{Na}^{+} \text {removal amount }(\mathrm{mmol} / \text { plant }) \\
& =\sum_{\mathrm{i}=1}^{4} \mathrm{SSR}_{\mathrm{i}} \times \mathrm{t}_{\mathrm{i}}
\end{aligned}
$$

where $\mathrm{SSR}_{\mathrm{i}}$ is the $\mathrm{Na}^{+}$removal rate $(\mathrm{mmol} /$ plant/d) during the $i^{\text {th }}$ week $(i=1,2,3$, and 4$)$, which can be determined from Eq. (4), and $t_{i}$ is the treatment time $(d)$ during the $i^{\text {th }}$ week $(i=1,2,3$, and 4). Eq. (6) was used for the calculation of total water consumption (L/ plant) of each plant.

$$
\text { Water consumption }(\mathrm{L} / \text { plant })=\frac{\sum_{\mathrm{i}=1}^{4} \Delta \mathrm{V}_{\mathrm{i}}}{4}
$$

where $\Delta \mathrm{V}_{\mathrm{i}}$ is the volume (L) of consumed water in each pot during the $\mathrm{i}^{\text {th }}$ week $(\mathrm{i}=1,2$, 3 , and 4 ), and the denominator in the formula, 4 , is the number of seedlings in each pot.

$\mathrm{Na}^{+}$removal efficiency $\left(\mathrm{mmol} \cdot \mathrm{kg}^{-1} \mathrm{DW}\right)$ and $\mathrm{Na}^{+}$uptake concentration $\left(\mathrm{mmol} \cdot \mathrm{L}^{-1} \mathrm{H}_{2} \mathrm{O}\right.$ ) were calculated as follows:

$$
\begin{aligned}
& \mathrm{Na}^{+} \text {removal efficiency }\left(\mathrm{mmol} \cdot \mathrm{kg}^{-1} \mathrm{DW}\right) \\
& =\frac{\text { SRA }}{\mathrm{DW}} \times 1000
\end{aligned}
$$

$\mathrm{Na}^{+}$uptake concentration $\left(\mathrm{mmol} \cdot \mathrm{L}^{-1} \mathrm{H}_{2} \mathrm{O}\right)$

$$
=\frac{\mathrm{SRA}}{\mathrm{WC}}
$$

In Eqs. (7) and (8), SRA is the total $\mathrm{Na}^{+}$ removal amount per plant (mmol/plant), which is determined from Eq. (5). In Eq. (7), DW is the dry weight per plant (g/plant). In Eq. (8), WC is the total water consumption of each plant (L/plant), which can be determined from Eq. (6). 

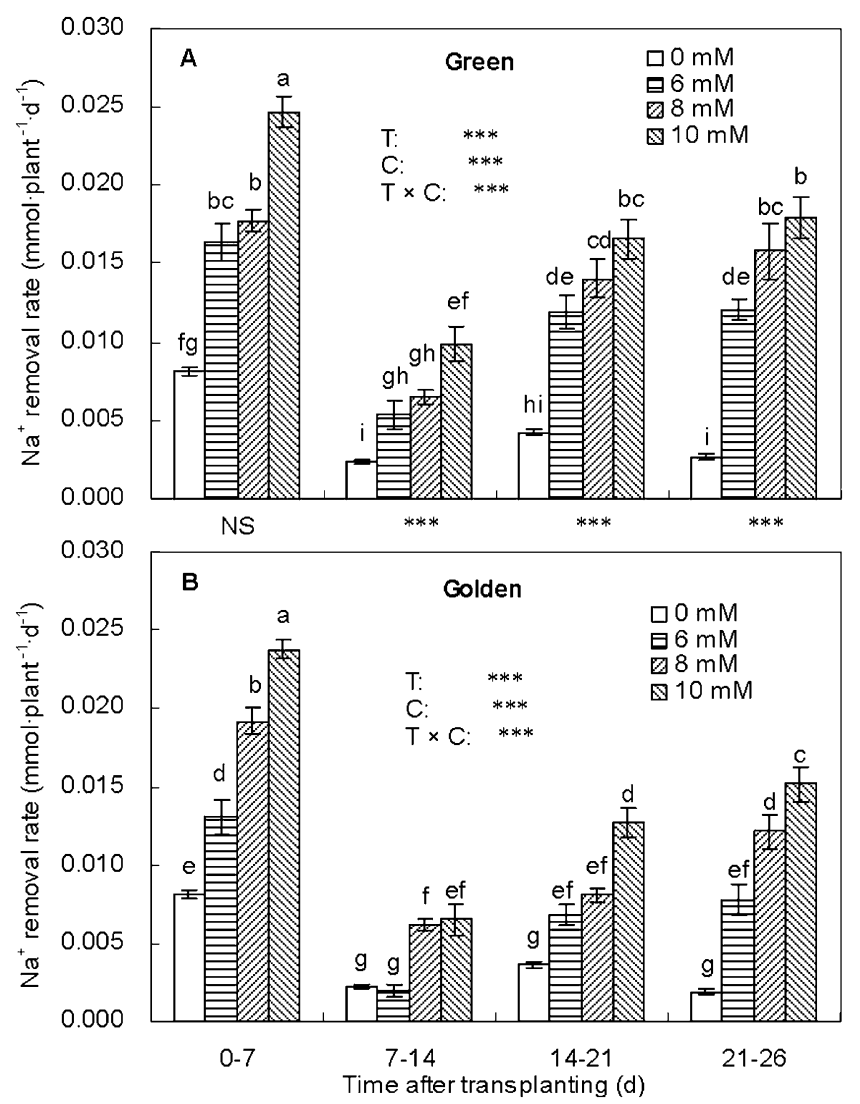

Fig. 3. Sodium (Na) removal rate of 'Green' (A) and Golden' (B) purslane grown in hydroponic solutions with different added $\mathrm{NaCl}$ concentrations at different growth stages. Data are means $\pm \mathrm{SE}(\mathrm{n}=10)$. Bars bearing the same letter are not significantly different at $P \leq 0.05$ according to Duncan's new multiple range test. At the same time points after transplanting, NS or *** between $(\mathbf{A})$ and $(\mathbf{B})$ indicates that the differences between the two cultivars are not significant or significant at $P \leq 0.001$, respectively. Within the same cultivar, time after transplanting $(\mathrm{T}), \mathrm{NaCl}$ concentration $(\mathrm{C})$, or the interaction of time after transplanting and $\mathrm{NaCl}$ concentration $(\mathrm{T} \times \mathrm{C})$, followed by $* * *$ denote treatment effects are significant at $P \leq 0.001$, respectively.

Statistical analysis. Data were subjected to analysis of variance using DPS (Data Processing System) Software (Version 7.05; Refine Information Tech. Co., Hangzhou, China) and were presented as mean $\pm \mathrm{SE}$; separation of means was performed using Duncan's new multiple range test at the $P \leq$ 0.05 level. Regression analyses were used to determine the relationship between purslane $\mathrm{Na}^{+}$removal and nutrient solution $\mathrm{NaCl}$ concentrations.

\section{Results}

Apparent growth. Apparent growth was not significantly affected by $\mathrm{NaCl}$ concentrations at any given time point during the $26 \mathrm{~d}$ of the study, but significant differences were obtained in most of the growth attributes between the two purslane cultivars (Fig. 1). The green-leafed cultivar had a longer main stem and wider canopy coverage than the golden-leafed one, which appeared to be more dwarfed and compact (Figs. 1A and 1D). Also, 'Golden' exhibited a shorter vegetative growth period than 'Green', because the terminal flower bud cluster appeared on $76.9 \%$ and $100 \%$ of the tested plants in 'Golden', but on only $0.6 \%$ and $38.8 \%$ of those in 'Green' at 16 and $26 \mathrm{~d}$ after transplanting, respectively.
Biomass accumulation. The rate of purslane biomass accumulation accelerated gradually after transplanting. The FW increase rate showed more than 2 -fold increase during the trial, from 0.51 to $1.22 \mathrm{~g} / \mathrm{plant} / \mathrm{d}$ in 'Green' and from 0.44 to $1.26 \mathrm{~g} / \mathrm{plant} / \mathrm{d}$ in 'Golden', respectively (Fig. 2). $\mathrm{NaCl}$ significantly affected the FW increase rate in 'Golden' but not in 'Green'. 'Golden' treated by $10 \mathrm{~mm} \mathrm{NaCl}$ had a higher FW increase rate compared with 0 to $8 \mathrm{~mm} \mathrm{NaCl}$ treatments 14 to $26 \mathrm{~d}$ after transplanting (Fig. 2B). On average, 'Green' exhibited a higher FW increase rate than 'Golden' from 0 to $21 \mathrm{~d}$ after transplanting.

At the time of harvest, the FWs and DWs and marketable yield were not significantly reduced by 6 to $10 \mathrm{~mm} \mathrm{NaCl}$ treatments compared with $0 \mathrm{~mm}$ added $\mathrm{NaCl}$ (Table 2). Furthermore, the $10 \mathrm{~mm} \mathrm{NaCl}$ treatment led to a higher DW of individual plants in 'Golden' and greater water use efficiency in both cultivars than the controls. On average, individual 'Green' plants had significantly higher FWs and DWs and marketable yields than 'Golden', but no significant difference in water use efficiency.

Sodium removal. There were significant differences in sodium removal rates among different growth stages of purslane; each plant removed 2- to 4-fold greater mmol of sodium per day during 0 to $7 \mathrm{~d}$ than during 7 to $26 \mathrm{~d}$ after transplanting (Fig. 3). However, the significant cultivar differences were mainly observed during the latter stages rather than the former ones.

At final harvest, the amount of sodium removed by purslane increased linearly with the increase of $\mathrm{Na}^{+}$as well as added $\mathrm{NaCl}$ concentrations in the nutrient solutions for both 'Green' and 'Golden' (Fig. 4A). Compared with $0 \mathrm{~mm} \mathrm{NaCl}$, plants treated with 6 to $10 \mathrm{~mm} \mathrm{NaCl}$ removed more than 2 - or 3 -fold sodium (up to 0.24 to $0.41 \mathrm{mmol} /$ plant) but consumed similar amounts of water per plant (Fig. 4A-B). Similarly, there were significant linear relationships between $\mathrm{Na}^{+}$removal efficiency $\left(\mathrm{mmol} \cdot \mathrm{kg}^{-1} \mathrm{DW}\right), \mathrm{Na}^{+}$ uptake concentration $\left(\mathrm{mmol} \cdot \mathrm{L}^{-1} \mathrm{H}_{2} \mathrm{O}\right.$ ) and $\mathrm{Na}^{+}$ as well as added $\mathrm{NaCl}$ concentrations (Fig. $4 \mathrm{C}$ D). On average, 'Green' showed significantly higher sodium removal, greater water consumption, and better $\mathrm{Na}^{+}$uptake concentration than 'Golden' (Figs. 4A-B and 4D). However, no significant cultivar difference was obtained for $\mathrm{Na}^{+}$removal efficiency (Fig. 4C).

\section{Discussion}

Impacts of moderate $\mathrm{NaCl}$ salinity on hydroponic production and sodium removal of purslane. Compared with $0 \mathrm{~mm} \mathrm{NaCl}, 6$ to $10 \mathrm{~mm} \mathrm{NaCl}$ treatments did not inhibit apparent growth or reduce biomass accumulation and final yield in purslane in our study. However, reductions in plant growth caused by $\mathrm{NaCl}$-dominated salinity were reported in several previous studies on purslane (Franco et al., 2011; Yazici et al., 2007). The discrepancy may be the result of differences in solution salinity levels; the EC values were less than $4.5 \mathrm{dS} \cdot \mathrm{m}^{-1}$ in our study but higher than $6.5 \mathrm{dS} \cdot \mathrm{m}^{-1}$, even up to $20 \mathrm{dS} \cdot \mathrm{m}^{-1}$ in previous studies. Purslane has been rated as a salinity-tolerant species with a yield threshold of $6.3 \mathrm{dS} \cdot \mathrm{m}^{-1}$ (Shannon and Grieve, 1999). Teixeira and Carvalho (2008) also showed that salinity-induced growth inhibition and biomass reduction were only observed in plants exposed to solutions with EC levels greater than $6.8 \mathrm{dS} \cdot \mathrm{m}^{-1}(\approx 60 \mathrm{~mm} \mathrm{NaCl})$.

In the present study, $10 \mathrm{~mm}$ added $\mathrm{NaCl}$ treatment $\left(\approx 12 \mathrm{mM} \mathrm{Na}^{+}\right.$actual concentration) promoted dry biomass accumulation in 'Golden', suggesting sodium could be a beneficial element for this purslane cultivar. Recently, it has also reported that sodium, at reasonable concentrations, can promote biomass yield of some species including asparagus, barley, broccoli, carrot, pea, cabbage, kale, mustard, radish, celery, sugar beet, red beet, and turnip (Subbarao et al., 2003). For hydroponic production of purslane, it is clear that an addition of 6 to $10 \mathrm{~mm} \mathrm{NaCl}$ to a solution (with an actual $\mathrm{Na}^{+}$concentration of $\approx 8$ to $12 \mathrm{~mm}$ ) is not harmful, but rather beneficial for biomass accumulation, although for hydroponic production of most fruit vegetables (e.g., cucumber and tomato), these concentrations of $\mathrm{Na}^{+}$may be damaging (Van Os, 1998, 1999). 

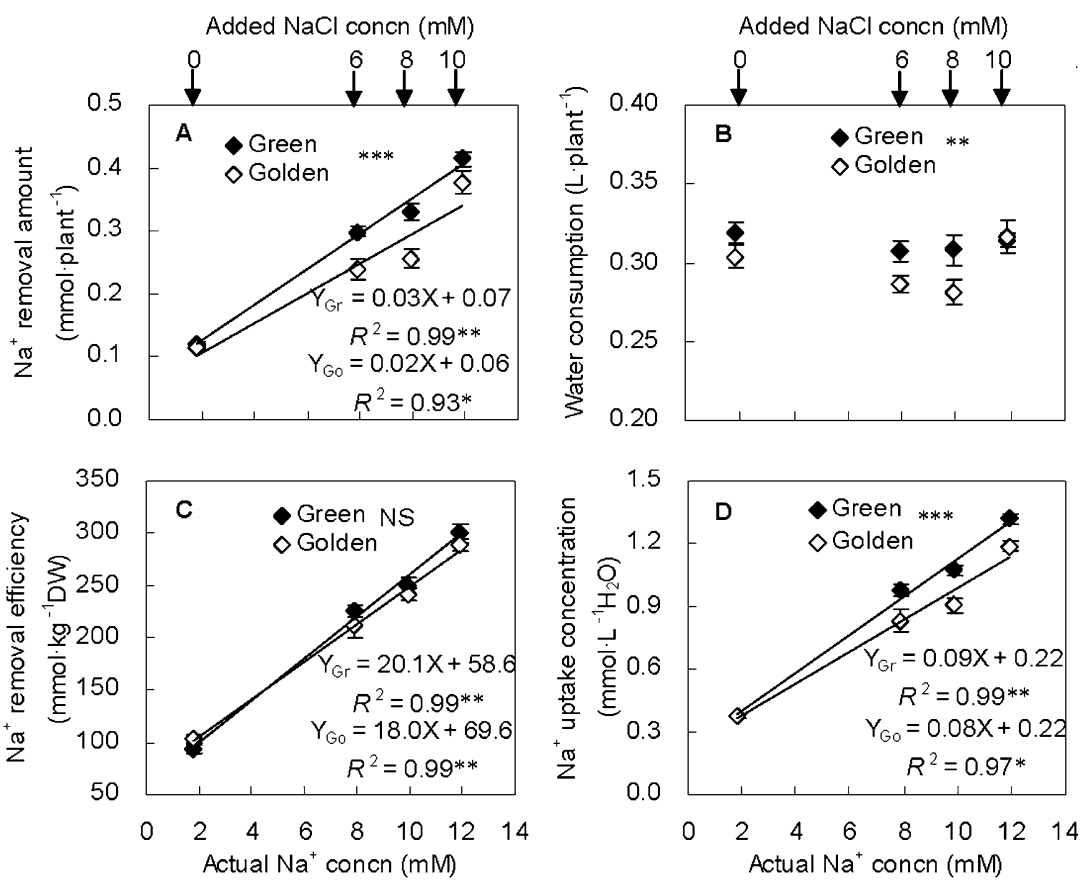

Fig. 4. $\mathrm{Na}^{+}$removal amount $(\mathbf{A})$, water consumption $(\mathbf{B}), \mathrm{Na}^{+}$removal efficiency $(\mathbf{C})$, and $\mathrm{Na}^{+}$uptake concentration (D) of 'Green' and 'Golden' purslane grown in hydroponic solutions with different added $\mathrm{NaCl}$ concentrations. Data are means $\pm \mathrm{SE}(\mathrm{n}=10)$. NS, $* *$, or $* * *$ behind the cultivar names indicates that the differences between the two cultivars are not significant or significant at $P \leq 0.01$ or 0.001 , respectively. Where $\mathrm{NaCl}$ concentration effects are significant at $P \leq 0.05$ or 0.01 , lines indicate the calculated regression; otherwise, no lines are shown. Gr and Go indicate purslane cultivars Green and Golden, respectively.

Purslane was reported to preferentially absorb $\mathrm{Na}^{+}$over other cations (e.g., $\mathrm{K}^{+}, \mathrm{Ca}^{2+}$ and $\mathrm{Mg}^{2+}$ ) with a 5- to 6-fold increase in shoot $\mathrm{Na}^{+}$concentration when root zone salinity level increased from 2.1 to $28.5 \mathrm{dS} \cdot \mathrm{m}^{-1}$ (corresponding $\mathrm{Na}^{+}$concentrations ranged from 15 to $275 \mathrm{~mm}$; Grieve and Suarez, 1997). In the present study, when the added $\mathrm{NaCl}$ concentration increased from 0 to 6 to $10 \mathrm{~mm}$ (actual $\mathrm{Na}^{+}$concentration increased from $\approx 2$ to 8 to $12 \mathrm{~mm}$ ) at a smaller interval, sodium removal by the purslane plants showed more than 2- or 3-fold increase. However, in fruit vegetables such as sweet pepper, less than 2- and 3-fold increase of $\mathrm{Na}^{+}$accumulation (based on DW) was obtained in its leaves and fruits, respectively, when $\mathrm{NaCl}$ concentration in nutrient solution increased from 0 to $15 \mathrm{~mm}$ (Rubio et al., 2011). It appeared that sodium removal in purslane was sensitive to a small change in $\mathrm{NaCl}$ concentration of the root zone solution, which might affect the relative availability of $\mathrm{Na}^{+}$to the plant root system (Grattan and Grieve, 1998; Teixeira and Carvalho, 2008).

Also, it should be noticed that under moderate $\mathrm{NaCl}$ salinity, purslane has superior sodium removal ability compared with common fruit vegetable crops. For example, tomato, as a salt-tolerant fruit vegetable, can only uptake $0.53 \mathrm{mmol} \mathrm{Na} \mathrm{L}^{-1} \mathrm{H}_{2} \mathrm{O}$ from solution with $19 \mathrm{~mm} \mathrm{NaCl}$ (Varlagas et al., 2010) and purslane, as shown in the present study, removed $\approx 1.3 \mathrm{mmol} \mathrm{Na}^{+} \mathrm{L}^{-1} \mathrm{H}_{2} \mathrm{O}$ from the solution with $\approx 12 \mathrm{mM} \mathrm{Na}^{+}$. Also, a previous study indicated that for the same plant, the sodium/water uptake ratio increased with the increase of root-zone $\mathrm{NaCl}$ concentration (Carmassi et al., 2005). Obviously, purslane could remove far more $\mathrm{Na}^{+}$from the nutrient solution with the same $\mathrm{Na}^{+}$concentration, if consuming the same amount of water, as tomato. One fact to be kept in mind is that a large amount of sodium was removed from the solutions, which could reduce the total amount of sodium discharged to the environment; however, the solution sodium concentrations were not reduced by purslane in our study (data not shown).

Comparison of two purslane cultivars for hydroponic production and sodium removal. The 'Green' and 'Golden' did not exhibit any visual stress symptoms induced by 6 - to 10-mM $\mathrm{NaCl}$ treatments indicating that both cultivars can tolerate these salinity levels. However, 'Green' exhibited more vigorous vegetative growth than 'Golden'. 'Green' Palaniswamy et al. (2000) also found similar cultivar differences in plant growth with the green-leafed purslane being taller and having a larger leaf area per plant than the goldenleafed one grown in solution without added $\mathrm{NaCl}$. Our study also showed that 'Green' had a longer vegetative growth period (as a result of a later appearance of flower buds) than 'Golden', indicating that 'Green' could be harvested as a leaf vegetable for a longer time.

Compared with 'Golden', 'Green' had a higher FW and DW per plant as well as a higher final marketable yield when grown at the same density. In non-NaCl-treated hydroponic had a longer main stem and larger canopy. solution, Palaniswamy et al. (2000) also reported that a green-leafed purslane showed higher FW and DW than a golden-leafed one. On the contrary, Lara et al. (2011) reported that a golden-leafed purslane cultivar had higher FW and DW than a green-leafed Spanish accession, C-215. Nevertheless, a common point in the two studies is that the purslane genotypes with higher biomass accumulation had a larger leaf area or a longer main stem regardless of leaf color. In another previous study, it was reported that fresh yield showed a positive linear relationship with main stem length, which was considered as a selection criteria for predicting purslane yield potential (Elmi et al., 1997). Thus, it seemed that the higher biomass accumulation and final yield of 'Green', in the present study, might not be associated with its leaf color, but with its longer main stem.

Significant cultivar differences also occurred in $\mathrm{Na}^{+}$removal ability; 'Green' removed more $\mathrm{Na}^{+}$per plant and showed a higher $\mathrm{Na}^{+}$ uptake concentration than 'Golden'. There are several possible explanations for the differences: 1) it might be associated with a greater biomass accumulation in 'Green'. A recent study on Salicornia europaea also indicated a tight coupling of biomass accumulation with sodium uptake (Lv et al., 2012); 2) it could be that 'Green' had a longer vegetative growth period than 'Golden', because plants translocate more $\mathrm{Na}^{+}$to vegetative structures than to reproductive structures (Subbarao et al., 2003). 'Green' and 'Golden' had a similar sodium removal efficiency based on plant DW (mmol. $\left.\mathrm{kg}^{-1} \mathrm{DW}\right)$. It may suggest that the two cultivars have similar $\mathrm{NaCl}$ salinity tolerance, because plant salt tolerance can be positively correlated with $\mathrm{Na}^{+}$accumulation in plant tissues (Glenn et al., 1999).

Overall, it appeared that 'Green' had greater potential for hydroponic production as a vegetable than 'Golden' based on individual plant performance; based on a group of plants, 'Golden' may achieve higher biomass yield per unit area in the greenhouse through a higher planting density than 'Green'. 'Golden' had more of a dwarfed and compact canopy than 'Green'.

Effects of growth stage on biomass production and sodium removal of purslane. Our results suggest that purslane has a higher sodium removal rate in each plant during the first $7 \mathrm{~d}$ of growth than at the later growth stages, which is consistent with results reported by Uddin et al. (2012a), who reported a decrease in dry leaf concentration of $\mathrm{Na}^{+}$as purslane plants matured. These facts indicate that purslane plants have the ability to control $\mathrm{Na}^{+}$absorption and it could increase with time. A similar phenomenon was observed in wheat (Rivelli et al., 2002) and barley (Jeschke and Wolf, 1985; Rawson et al., 1988). The physiological basis for these responses is not known, although it is possible to be explained as follows. When a plant is exposed to a saline solution for the first time, a large amount of absorption of $\mathrm{Na}^{+}$could provide a rapid means of turgor adjustment for plants to match the abrupt decrease in osmotic potential of the 
medium (Bernstein, 1975; Essah et al., 2003; Raven, 1985). Afterward, to avoid the toxicity of excessive $\mathrm{Na}^{+}$accumulation, a plant could initiate many other osmotic adjustment ways such as synthesis of proline (Yazici et al., 2007), which would reduce $\mathrm{Na}^{+}$uptake.

Unlike the pattern of $\mathrm{Na}^{+}$absorption, the accumulation rate of fresh biomass in each plant increased gradually after transplanting, indicating that the yield efficiency of individual purslane plants could increase gradually with the delay of harvest time. It appeared that the period of maximum biomass accumulation rate did not match that of maximum sodium removal rate in individual plants. This contradiction implied that an earlier harvest (for example, $7 \mathrm{~d}$ after transplanting) of purslane plants would reduce the biomass accumulation to a large degree despite having the highest sodium removal rate in individual plants during this period and despite having the advantage of shortening crop production time.

It may be possible to compromise the contradiction derived from an earlier harvest at the level of group plants vs. individual plants by increasing the planting density, because the earlier the harvest time, the smaller the canopy width of individual plants (Fig. 1). Another possibility is to introduce larger purslane plants into $\mathrm{NaCl}$-rich solutions only 1 week before harvest, which may maximize efficiency of both biomass accumulation and sodium removal. However, these speculations need further research for support.

In conclusion, it is possible to hydroponically produce purslane in nutrient solutions with 8 to $12 \mathrm{~mm} \mathrm{Na}^{+}$. Although purslane has a higher sodium-removal capability than common fruit vegetables, it cannot be used to reduce $\mathrm{Na}^{+}$concentration in $\mathrm{NaCl}$-rich hydroponic solutions. The biomass yield and the sodium removal of individual purslane plants can be affected by different cultivars and time after transplanting.

\section{Literature Cited}

Aksoy, U., H. Kayikçioglu, Y.S. Kukul, S. Hepaksoy, H.Z. Can, and B. Balci. 2003. An environmentally friendly technique to control salination: Salt removing crops. Acta Hort. 598:137142.

Bernstein, L. 1975. Effects of salinity and sodicity on plant growth. Annu. Rev. Phytopathol. 13: 295-312.

Carmassi, G., L. Incrocci, R. Maggini, F. Malorgio, F. Tognoni, and A. Pardossi. 2005. Modeling salinity build-up in recirculating nutrient solution culture. J. Plant Nutr. 28:431-445.

Cros, V., J.J. Martı'nez-Sa'nchez, and J.A. Franco. 2007. Good yields of common purslane with a high fatty acid content can be obtained in a peat-based floating system. HortTechnology 17:14-20.
Elmi, A.A., T. Mebrahtu, T.R. Omara-Alwala, and M. Ezekwe. 1997. Environmental effects on yield and agronomic traits of purslane (Portulaca spp.). Va. J. Sci. 48:203-210.

Essah, P.A., R. Davenport, and M. Tester. 2003. Sodium influx and accumulation in Arabidopsis. Plant Physiol. 133:307-318.

Franco, J.A., V. Cros, M.J. Vicente, and J.J. Martínez-Sánchez. 2011. Effects of salinity on the germination, growth, and nitrate contents of purslane (Portulaca oleracea L.) cultivated under different climatic conditions. J. Hort. Sci. Biotechnol. 86:1-6.

Glenn, E.P., J.J. Brown, and E. Blumwald. 1999 Salt tolerance and crop potential of halophytes. Crit. Rev. Plant Sci. 18:227-255.

Grattan, S.R. and C.M. Grieve. 1998. Salinitymineral nutrient relations in horticultural crops. Sci. Hort. 78:127-157.

Grieve, C.M. and D.L. Suarez. 1997. Purslane (Portulaca oleracea L.): A halophytic crop for drainage water reuse systems. Plant Soil 192:277-283.

Jeschke, W.D. and O. Wolf. 1985. $\mathrm{Na}^{+}$-dependent net $\mathrm{K}^{+}$-retranslocation in leaves of Hordeum vulgare, cv. California Mariout and Hordeum distichon, cv. Villa under salt stress. J. Plant Physiol. 121:211-223.

Kaşkar, Ç., J.A. Fernándeza, J. Ochoa, D. Niñirola, E. Conesa, and Y. Tüzel. 2008. Agronomic behaviour and oxalate and nitrate content of different purslane cultivars (Portulaca oleracea) grown in a hydroponic floating system. Acta Hort. 807:521-526.

Kilic, C.C., D. Anac, U. Aksoy, and S. Anac. 2010. Purslane and natural vegetation as bioremediation tools to cope salinity in Satsuma mandarin orchards. Afr. J. Agr. Res. 5:3316-3321.

Kilic, C.C., Y.S. Kukul, and D. Anac. 2008 Performance of purslane (Portulaca oleracea L.) as a salt-removing crop. Agr. Water Mgt. 95:854-858

Kronzucker, H.J. and D.T. Britto. 2011. Sodium transport in plants: A critical review. New Phytol. 189:54-81.

Lara, L.J., C. Egea-Gilabert, D. Niñirola, E. Conesa, and J.A. Fernández. 2011. Effect of aeration of the nutrient solution on the growth and quality of purslane (Portulaca oleracea). J. Hort. Sci. Biotechnol. 86:603-610.

Liu, S. 2002. Modern and practical soilless cultivation technology. China Agricultural Press, Beijing, China.

Lv, S., P. Jiang, X. Chen, P. Fan, X. Wang, and Y. Li. 2012. Multiple compartmentalization of sodium conferred salt tolerance in Salicornia europaea. Plant Physiol. Biochem. 51:47-52.

Munns, R. and M. Tester. 2008. Mechanisms of salinity tolerance. Annu. Rev. Plant Biol. 59: 651-681.

Palaniswamy, U.R., R.J. McAvoy, and B.B. Bible. 2000. Omega-3-fatty acid concentration in Portulaca oleracea is altered by nitrogen source in hydroponic solution. J. Amer. Soc. Hort. Sci. 125:190-194.

Raven, J.A. 1985. Regulation of $\mathrm{pH}$ and generation of osmolarity in vascular plants: A cost-benefit analysis in relation to efficiency of use of energy, nitrogen and water. New Phytol. 101:25-77.
Rawson, H.M., M.J. Long, and R. Munns. 1988. Growth and development in $\mathrm{NaCl}$-treated plants. I. Leaf $\mathrm{Na}^{+}$and $\mathrm{Cl}^{-}$concentrations do not determine gas exchange of leaf blades in barley. Funct. Plant Biol. 15:519-527.

Rivelli, A.R., R.A. James, R. Munns, and A.G.T Condon. 2002. Effect of salinity on water relations and growth of wheat genotypes with contrasting sodium uptake. Funct. Plant Biol. 29:1065-1074.

Rubio, J.S., W.E. Pereira, F. Garcia-Sanchez, L. Murillo, A.L. García, and V. Martínez. 2011. Sweet pepper production in substrate in response to salinity, nutrient solution management and training system. Hort. Brasileira. 29:275-281.

Savvas, D., V.A. Pappa, G. Gizas, and L. Maglaras. 2005. Influence of $\mathrm{NaCl}$ concentration in the irrigation water on salt accumulation in the root zone and yield in a cucumber crop grown in a closed hydroponic system. Acta Hort. 697: 93-98.

Seedaholic. 2013. Purslane ‘Golden Purslane’. 10 May 2013. <http://www.seedaholic.com/purslanesummer-purslane-golden-purslane.html>.

Shannon, M.C. and C.M. Grieve. 1999. Tolerance of vegetable crops to salinity. Sci. Hort. 78:538.

Subbarao, G.V., O. Ito, W.L. Berry, and R.M. Wheeler. 2003. Sodium-A functional plant nutrient. Crit. Rev. Plant Sci. 22:391-416.

Teixeira, M. and I.S. Carvalho. 2008. Effects of salt stress on purslane (Portulaca oleracea) nutrition. Ann. Appl. Biol. 154:77-86.

Tester, M. and R. Davenport. 2007. $\mathrm{Na}^{+}$tolerance and $\mathrm{Na}^{+}$transport in higher plants. Ann. Bot. (Lond.) 91:503-527.

Uddin, M.K., A.S. Juraimi, M.E. Ali, and M.R. Ismail. 2012a. Evaluation of antioxidant properties and mineral composition of purslane (Portulaca oleracea L.) at different growth stages. Intl. J. Mol. Sci. 13:10257-10267.

Uddin, M.K., A.S. Juraimi, F. Anwar, M.A. Hossain, and M.A. Alam. 2012b. Effect of salinity on proximate mineral composition of purslane (Portulca oleracea L.). Austral. J. Crop Sci. 6:1732-1736.

Van Os, E.A. 1998. Closed soilless growing systems in The Netherlands: The finishing touch. Acta Hort. 458:279-292.

Van Os, E.A. 1999. Closed soilless growing systems: A sustainable solution for dutch greenhouse horticulture. Water Sci. Technol. 39: 105-112.

Varlagas, H., D. Savvas, G. Mouzakis, C. Liotsos, I. Karapanos, and N. Sigrimis. 2010. Modelling uptake of $\mathrm{Na}^{+}$and $\mathrm{Cl}^{-}$by tomato in closed-cycle cultivation systems as influenced by irrigation water salinity. Agr. Water Mgt. 97:1242-1250.

Wenzel, G., J.D. Fontana, and J.C. Correa. 1990. The viscous mucilage from the weed Portulaca oleracea L. Appl. Biochem. Biotechnol. 24: 341-353.

Yazici, I., I. Turkan, A.H. Sekmen, and T. Demiral. 2007. Salinity tolerance of purslane (Portulaca oleracea L.) is achieved by enhanced antioxidative system, lower level of lipid peroxidation and proline accumulation. Environ. Exp. Bot. 61:49-57. 